\title{
DESIGN, IMPLEMENTATION AND ANALYSIS OF THE OVERALL PERFORMANCE OF A MICRO HYDRO TURGO TURBINE
}

\author{
Shpetim Lajqi', Qëndresa Bresa², Arlinda Bresa ${ }^{3}$, Ilir Doçi, Bojan Đurin ${ }^{5}$
}

\begin{abstract}
The increasing demand for energy and the concerns regarding environmental protection have been driving forces toward the exploitation of renewable energy sources as a better alternative compared to conventional energy sources. Furthermore, renewable energy sources enable an independent energy supply for isolated locations or communities that lack access to the main electricity grid, and additionally, they offer the possibility to use available energy sources for beneficial individual purposes. Considering these statements, the use of micro hydropower plants represents a convenient and advantageous option to implement. A micro hydro Turgo turbine is used for analysis in this paper, due to its simple design, structure, easy production and low installation cost.

In this manner, this paper deals with the use of Euler equations in detailed analysis in designing and implementation of a micro hydro Turgo turbine. The presented methodology will be based on numerical calculations of micro hydro Turgo turbine characteristic parameters in various operating regimes. The obtained results from numerical calculation will be compared to the current performance of the real existing Turgo turbine. Accordingly, based on obtained results, recommendations for improving the performance of micro hydro Turgo turbines will be presented.
\end{abstract}

Keywords: Design, Analysis, Micro Hydro Turgo Turbine, Performance, Turbine Efficiency

\section{INTRODUCTION}

Energy sources differ in their type and the way they are used to beneficially facilitate human life. As the demand for energy is increasing daily, researchers are focused to find the best solutions for energy production through clean and efficient ways. The energy of water presents a sustainable option in terms of Renewable Energy Source. Hydropower generation, portrays the shaft power that is retrieved from falling water which can be exploited for various mechanical purposes or more often for electricity generation, Raabe [1]. Hydropower, large and small, remains one among the most important of "renewables" electricity producers worldwide, producing around $19 \%$ of the electricity on the planet [2].

The term mini hydro refers to schemes between 100-500 [kW] (either as stand-alone schemes or more often feeding into the grid), micro-hydro between $5-100[\mathrm{~kW}]$ (usually provided power for small community or rural industry in remote areas away from the grid), Akella et al. [3], and Pico-hydro refers to schemes from a few hundred watts up to $5 \mathrm{~kW}$, Jawahar and Michael [4]. Many countries have established action plans and policies to anticipate the development of hydro energy systems, Yüksel [5]. This includes the initiative to develop small-scale hydro-electric power plants, with a variety of capacities between $1 \mathrm{~kW}$ up to $1 \mathrm{MW}$. A myriad of small, micro-hydropower plants have been designed and implemented, Lajqi et al. [6], including Pelton [6, 7], Turgo [8, 9, 10], Francis, Kaunda et al. [11], and Kaplan turbines. These turbines work with either high or medium water heads with a smaller amount of water flow, and various other turbines such as propeller and cross-flow turbines, which work under conditions of low water heads and large flow rates. Turgo turbine is assessed as an axial type of impulse turbine, which was invented and patented in 1920 by Gilbert Gilkes Ltd, Zidonis et al. [9]. These turbines are characterized by their robustness, reliability, and possibility to operate efficiently throughout a wide range of water flow rates, Williamson et al. [12]. They generate their torque through the change in momentum of an incoming jet of water, and they differ from Pelton turbines by the angle of the incoming jet. In Turgo turbines the jet enters and exits the wheel plane at an acute angle,

This paper was recommended for publication in revised form by Regional Editor Nader Javani

${ }^{1-4}$ University of Prishtina "HASAN PRISHTINA", Faculty of Mechanical Engineering, Prishtina, Republic of Kosovo

${ }^{5}$ University North, Department of Civil Engineering, Varaždin, Republic of Croatia

E-mail address: shpetim.lajqi@uni-pr.edu

Orcid id: 0000-0001-5091-2460, 0000-0003-1413-6358, 0000-0002-0702-5425, 0000-0003-3146-5305, 0000-0002-2361-8036

Manuscript Received 07 March 2020, Accepted 07 June 2020 
where the water coming from the bottom wheel goes without interfering with the incoming jet, as depicted in Figure 1. This enables the size reduction of the wheel, specifically the diameter for a given jet diameter and results in the increment of rotational speed, Gaiseret al. [13].

Micro hydropower plants present a convenient solution in terms of providing off-grid electricity in remote areas, hence, the design and planning of hydropower plants in isolated locations has been a focus of various researches for remote installations of Turgo turbines, such as by Ranjitkar et al. [14]. Pasalli et al. in [15] designed an impulse cross-flow turbine for remote use, and Kusakana [16] presented various technologies appropriate to be implemented in remote areas including Turgo turbines.

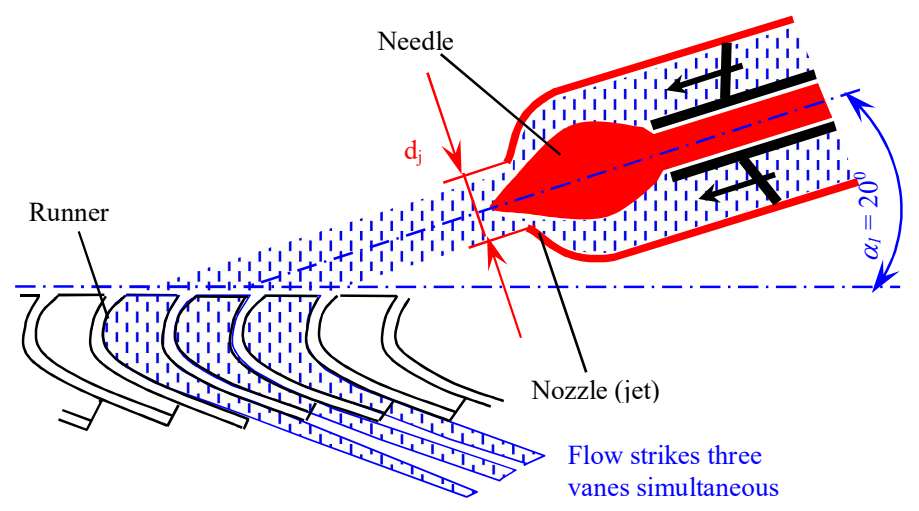

Figure 1. Direction of water flow for hydro Turgo turbine

Furthermore, different turbines used in micro-hydropower were examined and compared by Jawahar and Michael [4] and Nababan et al. [17], and the possibility to improve the efficiency of the Turgo turbines without compromising the cost was discussed. Additionally, the oversizing of turbines for low power production was addressed, which leads to increased losses and higher cost of the plant. Pico-hydropower plants are more common for rural isolated areas, as elaborated by Budiarso et al. [18]. In the sequential research from the same author, Budiarso et al. [19], another remote pico-hydro Turgo turbine was used to aim for higher turbine efficiency, through the optimal ratio of the physical characteristics of the turbine. Turgo turbines are often found in literature together with Pelton turbines, as in Cobb et al. [7] where the impact of speed ratio and jet position on the turbine efficiency were elucidated.

The establishing of dimensions and shape optimization of consisting parts of the Turgo turbine, has been an ongoing challenge to increase the efficiency of the turbine. The impact of specific parameters on the overall efficiency of the turbine was described by Williams et al. [20]. Another effort was reported by Gaiser et al. [13] who used mathematical modeling to determine the number and shape of blades, the jet diameter, and angle together with other characteristic dimensions. Likewise, detailed mathematical algorithms were used by Correa et al. [21], to study the particular three-dimensional flow to determine the best design solution of the blades. Originally, the blades of the runner were designed by utilizing velocity triangles to detect the optimal dimensions of the blades, consequently ensuring proper inlet and outlet angle of the water flow. This latter method was used to analyze the Turgo turbine in this present paper.

Apart from the physical structure of the turbine parts, the complex water flow in the runner was analyzed by Yaakob et al. in [22], who reports a review on suitable turbines to be used in micro-hydro with a focus on gravitational vortex of water flow. The advancement of computational performance has enabled the development of two major approaches used to analyze the complex water flow dynamics in the runner. These approaches are either by using Eulerian or mesh-based computations or by using Langrangian or mesh-less computations, Zidonis et al. [9]. Meshbased mathematical computations are used to describe the complex water flow through the blades, that require high computational resources, therefore some researches are leaning towards the mesh-less approach. An example is, Koukouvinis et al. [23] where a Smoothed Particle Hydrodynamic (SPH) algorithm was used which represents the water flow as a set of particles, then analyzes their individual trajectory in the runner. Furthermore, a comparative analysis was performed with a commercial Computational Fluid Dynamics (CFD) package Fluent, and the yielded 
Journal of Thermal Engineering, Research Article, Vol. 7, No. 4, pp. 806-822, May, 2021

results showed similar outcomes, although the SPH method was less time-consuming. Anagnostopoulos et al. [24] has developed a Fast Lagrangian Simulation (FLS) and analyze the water flow through particle motion equations.

More accurate results are obtained using CFD software to simulate the water flow. This is seen in the various researches such as Warjito et al. [25] where the design of Turgo buckets was described using velocity triangles and then validated using CFD simulations. Moreover, in [26] ANSYS CFD software was used to analyze the Turgo blades. The stress caused by the water jet was tested, concluding that the main stress occurs near the root of the suction site with a hit angle of $20^{\circ}$. The effect of the water jet on the blade surface is elaborated as well by Khurana et al. [27] pointing out the impact of jet velocity, working hours, the size, and concentration of the silt of water on the blades. This work was followed by two other publications with additional indicators on the material wear of the blade surface, including the effect of jet diameter on the erosion of the Turgo turbine blades, Khurana et al. [28], and the impact of silt size and concentration on the performance of the turbine, Khurana et al. [29]. Further, it was stated that the use of more jets with smaller diameters presents a better solution in terms of mitigating the normalized erosion wear rate of the runner. Thus, in the present paper four water jets are used in the implemented Turgo turbine.

Despite the individual use of hydro energy, increasing attention is paid recently towards the use of combined renewable energy sources such as hydro power and solar energy, also known as hybrid energy systems, which present a more efficient and sustainable solution. Hybrid energy systems, consisting of hydroelectric power plants and solar photovoltaic plants, are well-known and widely applied power generation systems. These systems differ in terms of the structural characteristics and power of hydro power plants. A notable example of a hybrid system is the world's first hybrid system with a floating solar photovoltaic power plant, built at the AltoRabagão dam in Montelegre, Portugal [30]. There are many "small scale" examples of hybrid systems in the world, such as in Taratak, Indonesia, a microhydro-PV power system, Muhida et al. [31] and an example of a hybrid system for remote villages in Cameroon, Nfah and Ngundam [32]. This present paper will be focused solely on the use of hydro energy, and future research will implement hybrid systems as well.

In Kosovo where the analyzed Turgo turbine is installed, according to statistics the hydro potential is very limited and can meet only $10-12 \%$ of the requirements of domestic electricity consumption [33,34]. Therefore, in order to use this hydro potential, the installment of micro-hydropower plants presents a convenient and beneficial solution.

Electrical energy is a basic necessity in the developing process of any given location or community, Dametew [35], therefore, rural electrification remains an important issue in many countries. More often rural areas are prone to several electrification problems, so the use of renewable energy sources represents a convenient and more sustainable alternative, to achieve optimum system design in terms of cost and efficient load demand satisfaction [36, 37].

Thereupon, in this paper, the analysis of an existing micro-hydro Turgo turbine is described, by comparing on-site measured parameters with analytical calculations, specifically by using Euler equations in simplified and detailed calculations. A case study is described where a Turgo turbine was designed and installed. The calculations performed in the design phase and the measurements conducted during the operational phase of the turbine are presented in the following sections, which aid in calculating the real and estimated output values for the power generated by the turbine.

\section{DESIGN OF A MICRO-HYDROPOWER PLANT}

In order to design a well-functioning micro-hydropower plant, there are several steps that have to be considered. Starting from onsite measurements of the landscape up to detailed calculations. The following sections present a step by step guideline that shows the prerequisites for determining the properties of the micro-hydropower plant.

\section{On-Site Data Measurements}

In order to calculate the power generation from the hydro turbine, prior data must be known and various parameters have to be determined. Two of the most important parameters are the water flow rate $(Q)$ and water fall head $(H)$. Water fall head also labeled in literature as gross head, which presents the vertical length between the free surface level of the water and the nozzle of impulse turbines such as hydro Turgo turbine. 
The net head $\left(H_{n}\right)$ is calculated by subtracting the hydraulic losses along the penstock from gross water head $\left(H_{g}\right)$. Hence the net head is computed by:

$$
H_{n}=H_{g}-H_{l o s}[m]
$$

The hydraulic penstock losses can be longitudinal and local losses. While losses along the penstock are:

$$
H_{\text {los }}=H_{\text {long }}+H_{\text {loc }}[m]
$$

where $H_{n}, H_{g}, H_{\text {los }}, H_{\text {long }}$ and $H_{\text {loc }}$ are the net head, gross head, hydraulic penstock losses, longitudinal and respectively local losses in the penstock.

Longitudinal losses $\left(H_{\text {long }}\right)$ occurring along the penstock are determined by:

$$
H_{\text {long }}=\frac{\lambda}{2} \cdot \frac{L}{d_{\text {in }}} \cdot \frac{v^{2}}{g}[m]
$$

Whereas local losses $\left(H_{l o c}\right)$ including losses through fittings, bends and so on are calculated by:

$$
H_{l o c}=\frac{k}{2} \cdot \frac{v^{2}}{g}[m]
$$

Water flow $(Q)$ can be determined either via on-site measurements in different methods or by estimation through calculations. The continuity expression shows the relation between the velocity of the fluid $(v)$ and the cross section $(A)$ of the penstock, hence:

$$
Q=v \cdot A\left[m^{3} / s\right]
$$

where $\lambda, L, d_{i n}, v, g, k, Q$ and $A$ are the friction coefficient of water with penstock, penstock length, penstock internal diameter, water velocity in penstock, gravity acceleration, coefficient of local losses, water flow rate, and penstock cross-section surface.

\section{Dimensional Analysis}

In regard to setting the dimensions of the hydro turbine, the following calculations are used with the assumption that the turbine is working with only one nozzle [38]. Many turbines work on different working regimes, using several nozzles, thus in order to perform computations for each of them, the flow has to be divided for the number of active nozzles.

The velocity of the water jet $\left(v_{1}\right)$ hitting the turbine runner blades (Figure 3) depends on the net head as shown below:

$$
v_{1}=C_{d} \cdot \sqrt{2 \cdot g \cdot H_{n}}[\mathrm{~m} / \mathrm{s}]
$$

The diameter of the water jet $\left(d_{j}\right)$ is necessary to obtain all other dimensions. It is calculated using the expression that links the flow and the water jet velocity (Figure 3): 


$$
d_{j}=\sqrt{\frac{2 \cdot Q}{\pi \cdot v_{1}}}[m]
$$

where $v_{1}, C_{d}$ and $d_{j}$ are the water jet velocity, discharge coefficient of jet and diameter presenting the water jet.

Figure 2 shows the design parameters of the hydro Turgo runner. The peripheral or tangential velocity of the turbine runner at the pitch circle $\left(u_{1}\right)$ is determined by speed ratio, written as follows:

$$
u_{1}=K \cdot v_{1}[\mathrm{~m} / \mathrm{s}]
$$

The speed ratio $(K)$ shows the ratio of the peripheral velocity at the pitch circle of the wheel compared to the actual jet velocity, Figure 2. In general, the value of speed ratio is $K=0.44 \ldots . .0 .50$ but for practical calculation, this ratio is given $K=0.49$.

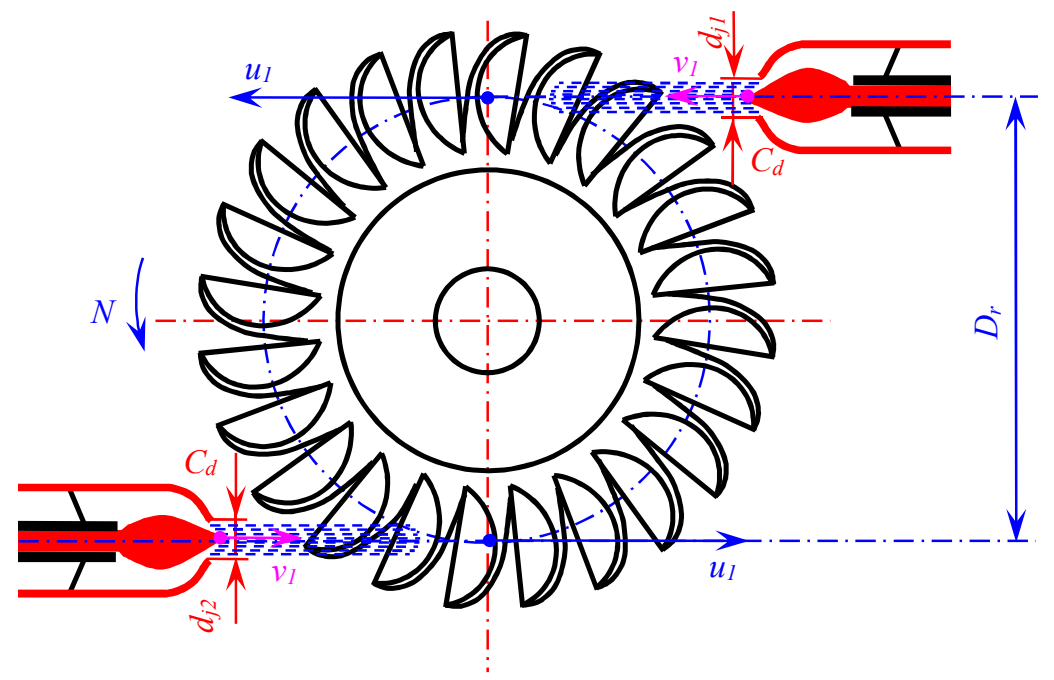

Figure 2. Design parameters of the hydro Turgo runner

There are numerous approaches to calculate the runner diameter $\left(D_{r}\right)$ for hydro Turgo turbine, Figure 2.

The most frequently used expressions for calculating the runner pitch diameter for hydro Turgo turbine is by employing peripheral velocity of the wheel at the pitch circle, as follows:

$$
D_{r}=\frac{60 \cdot u_{1}}{\pi \cdot N}=\frac{60 \cdot K \cdot C_{d} \cdot \sqrt{2 \cdot g \cdot H_{n}}}{\pi \cdot N}[\mathrm{~m}]
$$

where $u_{1}, K, D_{r}$, and $N$ are the turbine runner peripheral velocity, speed ratio, runner diameter, and rotation speed of the turbine (generator).

The values resulting from the estimated calculations taken from given expressions are then compared to the detailed calculations using Euler equations.

The output power $\left(P_{\text {out }}\right)$ from the hydro Turgo turbine can be determined by using the following expression:

$$
P_{\text {out }}=P_{\text {water }} \cdot \eta_{\text {turb }} \cdot \eta_{\text {gen }}=\rho \cdot g \cdot H_{n} \cdot Q \cdot \eta_{\text {turb }} \cdot \eta_{\text {gen }}[W]
$$

where $P_{\text {water }}, \eta_{\text {turb }}, \eta_{\text {gen }}$ and $\rho$ are the power of water flow, turbine efficiency, generator efficiency, and water density. 
Journal of Thermal Engineering, Research Article, Vol. 7, No. 4, pp. 806-822, May, 2021

Qualitative and detailed calculations are performed by using Euler turbine equations, which uses velocity triangles to predict the main parameters such as flow rate, power, and turbine efficiency.

Figure 3 shows the model velocity triangles designed by Williamson et al., where the velocity $v_{1}$ of the flow falling through a net head $H_{n}$ leaving the jet is calculated by expression (6).

The flow rate in the turbine is calculated from the equation of continuity is:

$$
Q=v_{1} \cdot \frac{\pi \cdot d_{j}^{2}}{4}=C_{d} \cdot \sqrt{2 \cdot g \cdot H_{n}} \cdot \frac{\pi \cdot d_{j}^{2}}{4}\left[\mathrm{~m}^{3} / \mathrm{s}\right]
$$

where $d_{j}$ is the jet diameter. When $d_{j}$ has a constant value, it shows that the increase of the water head results in the increment of the flow rate as well.

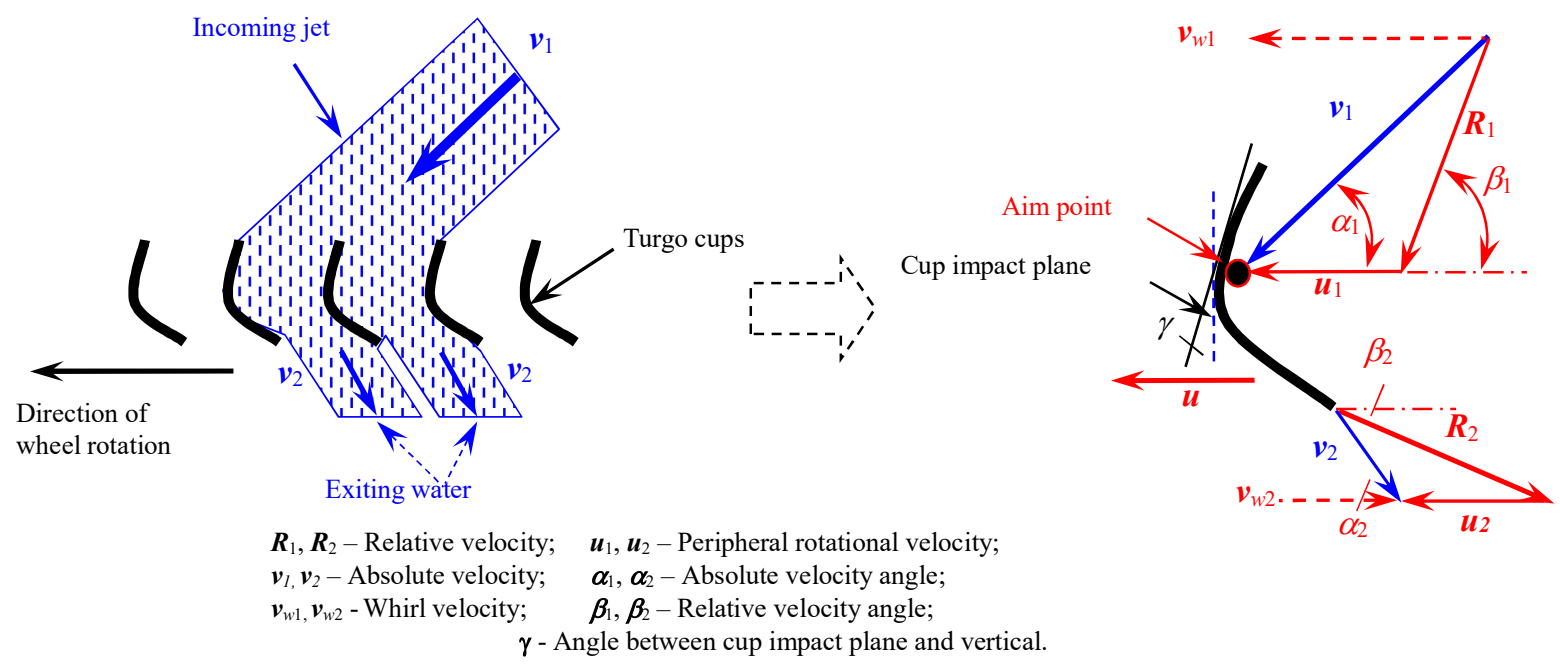

Figure 3. Velocity triangles of hydro Turgo turbine

The calculation of the proportion of water exiting the cup from the upper and lower edges is easier by using the momentum balance analysis for a jet hitting an inclined plate, which assumes that the cup is a flat plate at the point of impact for the jet center.

The inclination angle $\gamma$ is the angle between the cup impact plane and the vertical one. Flow rate exiting the bottom $Q_{2}$ and top $Q_{2}^{\prime}$ of the cup by applying the momentum balance analysis are:

$$
\begin{aligned}
& Q_{2}=\cos ^{2}\left(\frac{\beta_{1}+\gamma}{2}\right) \cdot Q\left[\mathrm{~m}^{3} / \mathrm{s}\right] \\
& Q_{2}^{\prime}=\sin ^{2}\left(\frac{\beta_{1}+\gamma}{2}\right) \cdot Q\left[\mathrm{~m}^{3} / \mathrm{s}\right]
\end{aligned}
$$

The change in the whirl velocity $\left(v_{w}-\right.$ absolute velocity in the plane of rotation of the wheel) can be calculated by the following expression:

$$
\Delta v_{w}=v_{w 1}+v_{w 2}=v_{1} \cdot \cos \alpha_{1}-u_{1}+\left(\frac{v_{1} \cdot \sin \alpha_{1} \cdot \cos \beta_{2}}{\sin \beta_{1}}\right)[\mathrm{m} / \mathrm{s}]
$$

The change in the whirl velocity for the top of the cup is written by the following expression: 
Journal of Thermal Engineering, Research Article, Vol. 7, No. 4, pp. 806-822, May, 2021

$$
\Delta v_{w}^{\prime}=v_{w 1}+v_{w 2}^{\prime}=v_{1} \cdot \cos \alpha_{1}-u_{1}+\left(\frac{v_{1} \cdot \sin \alpha_{1} \cdot \cos \beta_{2}^{\prime}}{\sin \beta_{1}}\right)[\mathrm{m} / \mathrm{s}]
$$

The following expression determines the equation for torque applied to the turbine, based on whirl velocity and flow rates:

$$
T=\rho \cdot\left(Q_{2} \cdot \Delta v_{w}+Q_{2}^{\prime} \cdot \Delta v_{w}^{\prime}\right) \cdot \frac{D_{r}}{2}[N \cdot m]
$$

The equation for the output power of the turbine, based on whirl velocity and flow rates is computed by the following expression:

$$
P_{\text {turb }}=T \cdot \omega=\rho \cdot\left(Q_{2} \cdot \Delta v_{w}+Q_{2}^{\prime} \cdot \Delta v_{w}^{\prime}\right) \cdot \frac{D_{r}}{2} \cdot \omega[W]
$$

The hydro Turgo turbine efficiency can be calculated from the output power produced by the turbine (equation 19) divided by the power of water flow:

$$
P_{\text {water }}=\rho \cdot g \cdot Q \cdot H_{n}[W]
$$

hence it is:

$$
\eta_{\text {turb }}=\frac{P_{\text {turb }}}{P_{\text {water }}}[\%]
$$

CASE STUDY: DESIGN AND IMPLEMENTATION OF A MICRO HYDRO TURGO TURBINE IN KOSOVO

A micro hydro turbine was designed and implemented in "ILLYRICUM PARK" Letnicë, Viti, Republic of Kosovo. Depending on the fact that in the designated location the available flow rate is: $Q=0.01-0.07\left[\mathrm{~m}^{3} / \mathrm{s}\right]$ and the gross head $H_{g}=47.5[\mathrm{~m}]$, it was estimated that the best suited turbine to work under such conditions is a Micro-Hydro Turgo turbine. The geometry of the analyzed turbine was conditioned by the parameters listed in Table 1.

Table 1. Input data for design micro hydro Turgo turbine

\begin{tabular}{|l|c|}
\hline Description of parameters & Value \\
\hline Gross Head, $H_{g}[\mathrm{~m}]$ & 47.50 \\
\hline $\begin{array}{l}\text { Penstock diameter, } D_{1}, D_{2}, D_{3} \\
{[\mathrm{~mm}]}\end{array}$ & $\varnothing 315, \varnothing 280, \varnothing 250$ \\
\hline Material of penstock & HDPE 100 \\
\hline Penstock length, $L_{1}, L_{2}, L_{3}[\mathrm{~m}]$ & $388,932,18$ \\
\hline Generator & $N=1500[\mathrm{rpm}], P_{\text {gen }}=20[\mathrm{~kW}], \eta_{\text {gen }}=85 \%$ \\
\hline Predicted turbine efficiency, $\eta_{t}$ & $80 \%$ \\
\hline Discharge coefficient of jet, $C_{d}$ & 0.95 \\
\hline Speed ratio, $K$ & 0.49 \\
\hline Water density, $\rho\left[\mathrm{kg} / \mathrm{m}^{3}\right]$ & 1000 \\
\hline Friction coefficient, $\lambda$ & 0.03 \\
\hline $\begin{array}{l}\text { Diameter of } 1^{\text {st }} \& 3^{\text {rd }} \text { nozzles, } \\
d_{j 1}=d_{j 3}[\mathrm{~mm}]\end{array}$ & 25 \\
\hline $\begin{array}{l}\text { Diameter of } 2^{\text {nd }} \& 4^{\text {th }} \text { nozzles, } \\
d_{j 2}=d_{j 4}[\mathrm{~mm}]\end{array}$ & 29 \\
\hline
\end{tabular}

The designed and installed hydro turbine has a total of four nozzles, which two by two have the same diameter where nozzles $d_{j 1}=d_{j 3}=25[\mathrm{~mm}]$, whereas nozzles $d_{j 2}=d_{j 4}=29[\mathrm{~mm}]$, Figure 4 . Hence, some of the combinations yield the same value and the total number variation is reduced to 8 working regimes. 


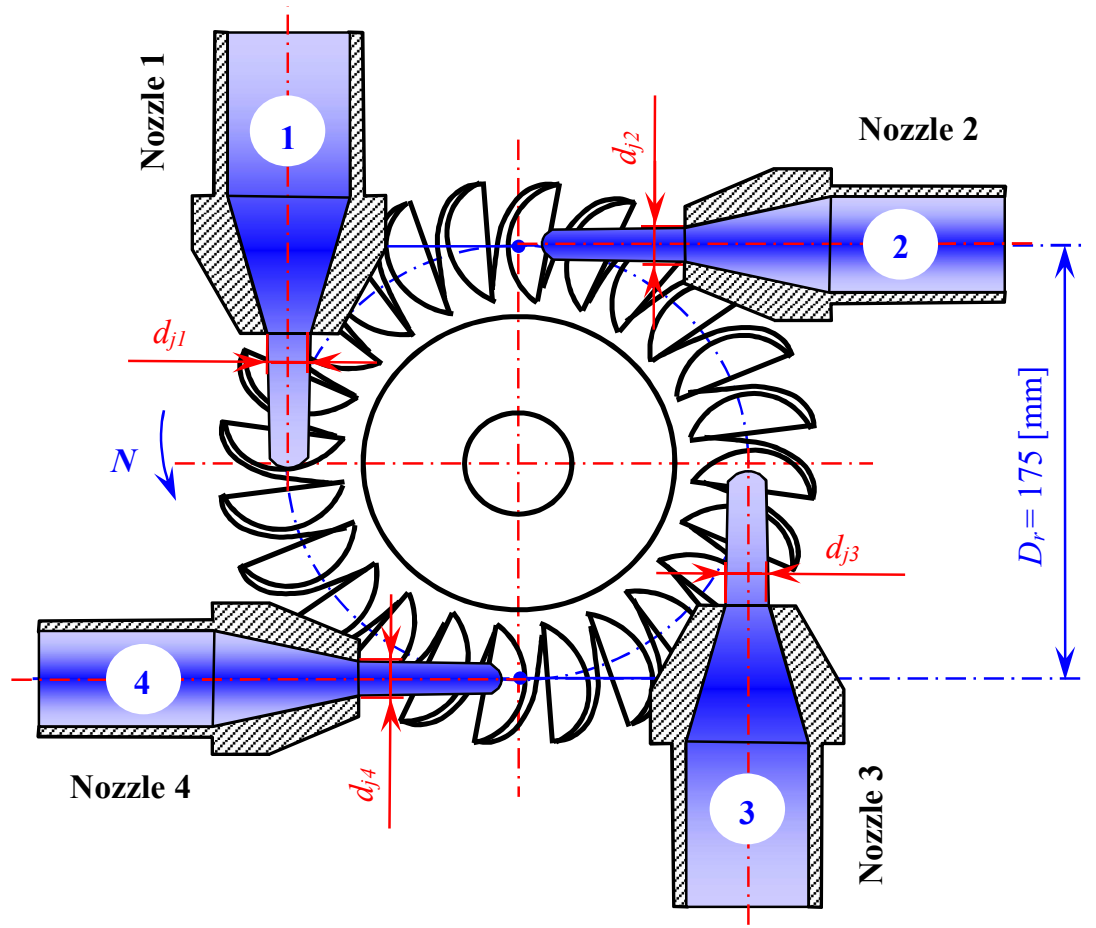

Figure 4. Configuration of nozzles in hydro Turgo turbine

Depending on the working regime, a set of 15 combinations of active nozzles (jets) are shown in Table 2. The regimes represent whether there is only one working nozzle or a combination of two or more nozzles named by their number order $1,2,3$ or 4 . When all nozzles are active the combination shows $1+2+3+4$, whereas when none of them are active, this is the $16^{\text {th }}$ combination showing that all nozzles are closed.

Table 2. Combination of nozzles, cross section and equivalent diameter of nozzles

\begin{tabular}{|c|c|c|c|}
\hline $\begin{array}{c}\text { Working } \\
\text { combinations }\end{array}$ & Active nozzles & $\begin{array}{c}\text { Cross section of nozzles, } \\
A_{j}=\frac{\pi \cdot d_{j}^{2}}{4}\left[\mathrm{~mm}^{2}\right]\end{array}$ & $\begin{array}{c}\text { Equivalent diameter of } \\
\text { nozzles, [mm] }\end{array}$ \\
$d_{j \text {-equivalent }}=\sqrt{\frac{4 \cdot A_{j}}{\pi}}[\mathrm{mm}]$
\end{tabular}


Journal of Thermal Engineering, Research Article, Vol. 7, No. 4, pp. 806-822, May, 2021

In order to calculate the required dimensions of the turbine and the penstock, initially the water jet velocity has been determined by using the measured water head. By replacing the input data presented in Table 1, the expressions from (1) until (12) are obtained result shown in Table 3.

Table 3. Net head, water jet velocity, water flow from nozzles, runner diameter and output power for Turgo Turbine

\begin{tabular}{|c|c|c|c|c|c|}
\hline $\begin{array}{c}\text { Working } \\
\text { combinations }\end{array}$ & $\begin{array}{c}\text { Net head, } \\
H_{n}[\mathrm{~m}]\end{array}$ & $\begin{array}{c}\text { Water jet velocity } \\
v_{1}=C_{d} \cdot \sqrt{2 \cdot g \cdot H_{n}}[\mathrm{~m} / \mathrm{s}]\end{array}$ & $\begin{array}{c}\text { Water flow, } \\
Q=v_{1} \cdot \frac{\pi \cdot d_{j}^{2}}{4}\left[\mathrm{~m}^{3} / \mathrm{s}\right]\end{array}$ & $\begin{array}{c}\text { Runner } \\
\text { diameter, } \\
D_{r}[\mathrm{~m}]\end{array}$ & $\begin{array}{c}\text { Output } \\
\text { power, } \\
P_{\text {out }}[\mathrm{W}]\end{array}$ \\
\hline 1 & 45.56 & 28.69 & 0.0141 & 0.179 & 4275.64 \\
\hline 2 & 44.90 & 28.53 & 0.0188 & 0.178 & 5639.64 \\
\hline 3 & 45.56 & 28.69 & 0.0141 & 0.179 & 4275.64 \\
\hline 4 & 44.90 & 28.53 & 0.0188 & 0.178 & 5639.64 \\
\hline 5 & 43.04 & 28.06 & 0.0323 & 0.175 & 9268.74 \\
\hline 6 & 43.70 & 28.06 & 0.0276 & 0.175 & 8023.81 \\
\hline 7 & 43.04 & 28.06 & 0.0323 & 0.175 & 9268.74 \\
\hline 8 & 43.04 & 28.06 & 0.0323 & 0.175 & 9268.74 \\
\hline 9 & 42.41 & 27.91 & 0.0369 & 0.174 & 10420.04 \\
\hline 10 & 43.04 & 28.06 & 0.0323 & 0.175 & 9268.74 \\
\hline 11 & 41.24 & 27.59 & 0.0453 & 0.172 & 12453.84 \\
\hline 12 & 40.68 & 27.27 & 0.0494 & 0.170 & 13393.41 \\
\hline 13 & 41.24 & 27.59 & 0.0453 & 0.172 & 12453.84 \\
\hline 14 & 40.68 & 27.27 & 0.0494 & 0.170 & 13393.41 \\
\hline 15 & 38.93 & 26.94 & 0.0620 & 0.168 & 16096.90 \\
\hline
\end{tabular}

The design of the hydro Turgo turbine is depicted in Figure 5, where the adequate dimensions were determined from the calculations.

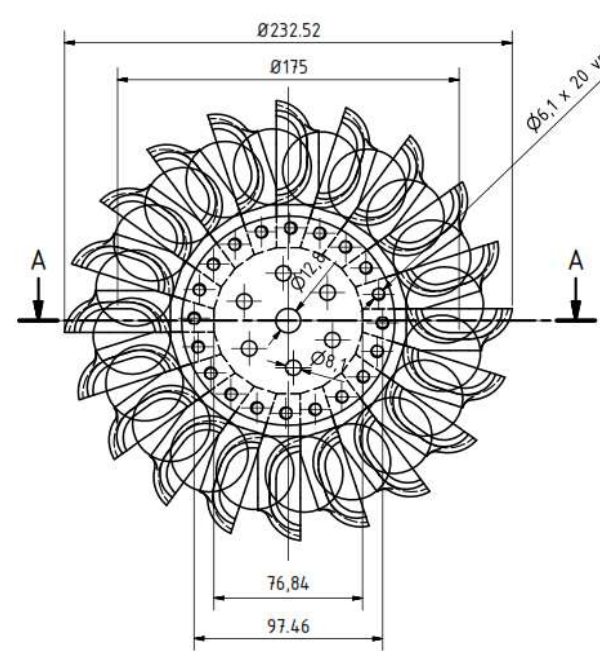

$A-A(1: 2)$

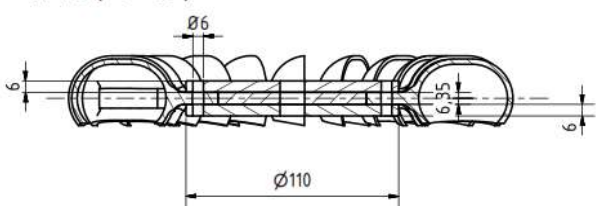

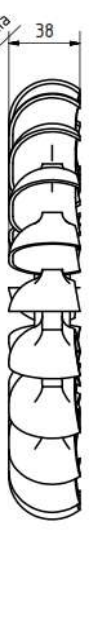
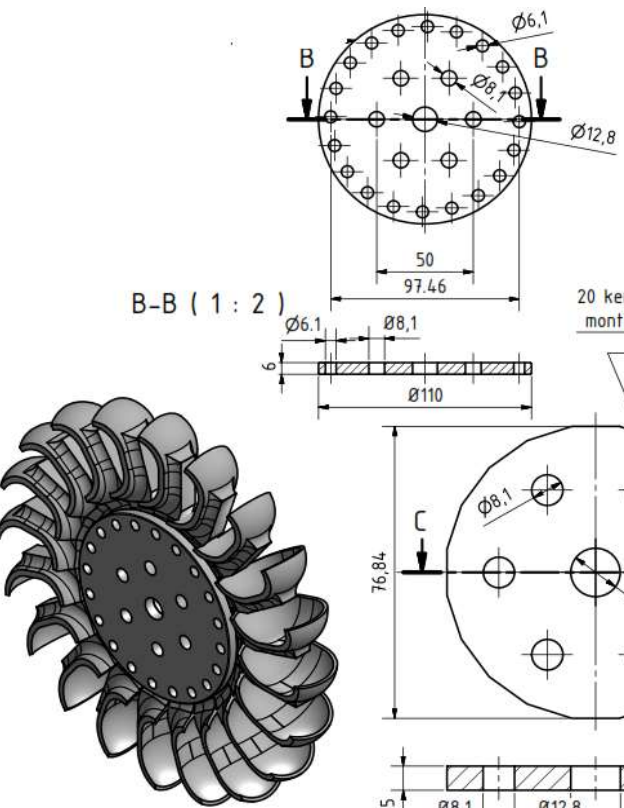

$B-B(1: 2)$

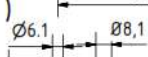

$\varnothing 6.1 \ldots 80.1$

Q610 montimin e lugeve

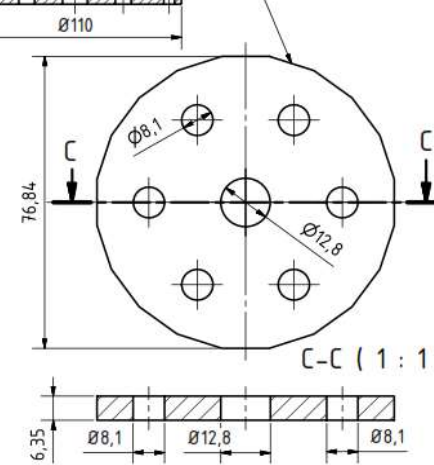


Journal of Thermal Engineering, Research Article, Vol. 7, No. 4, pp. 806-822, May, 2021
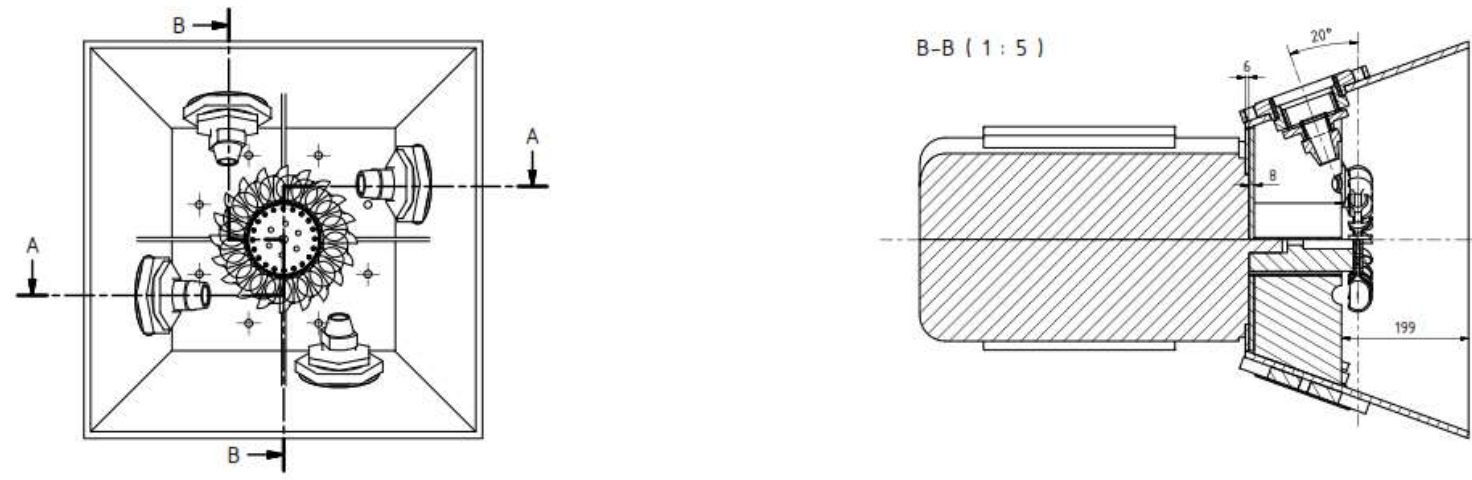

$A-A(1: 5)$
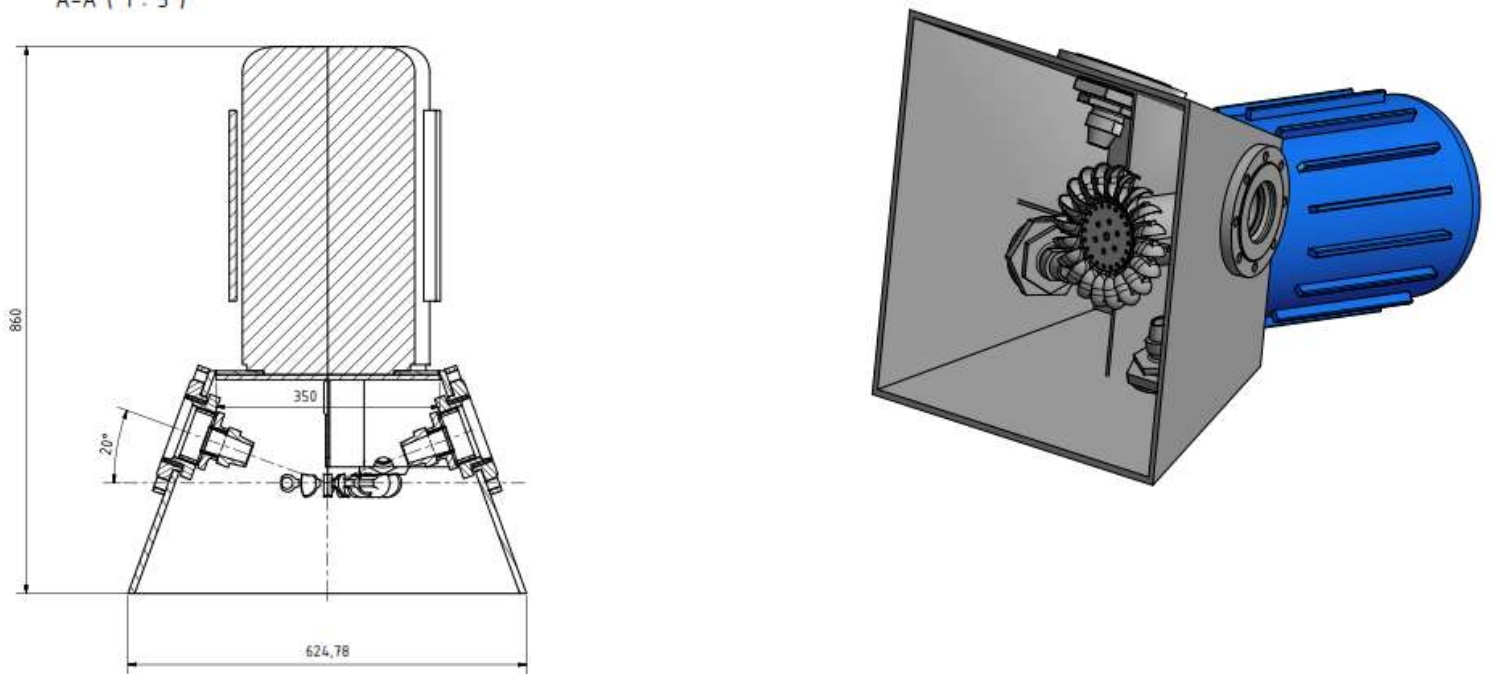

Figure 5. Design of the runner and the assembly of hydro Turgo turbine

Figure 6 shows the positioning of the hydro Turgo turbine in the hydropower plant house.

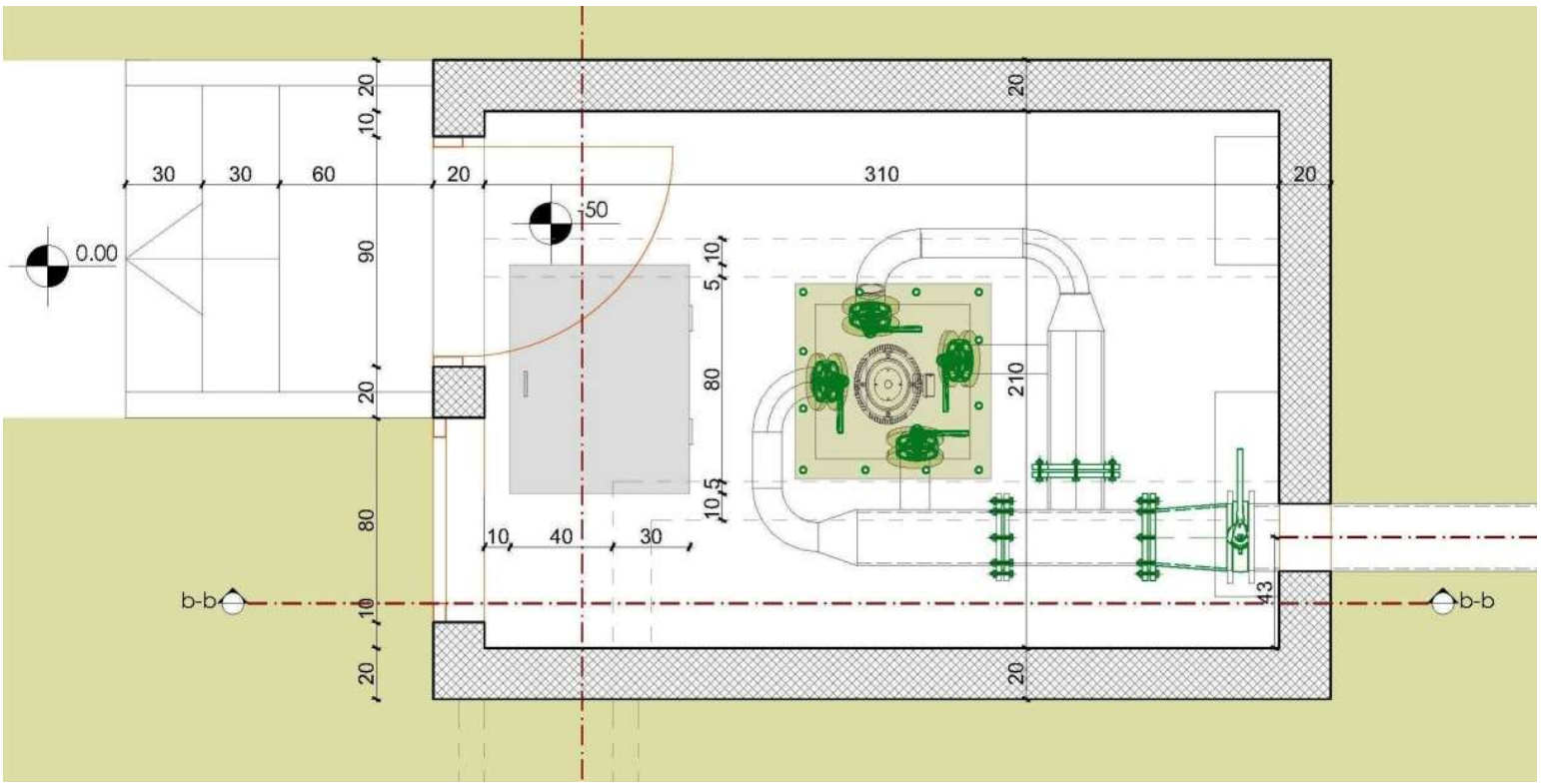



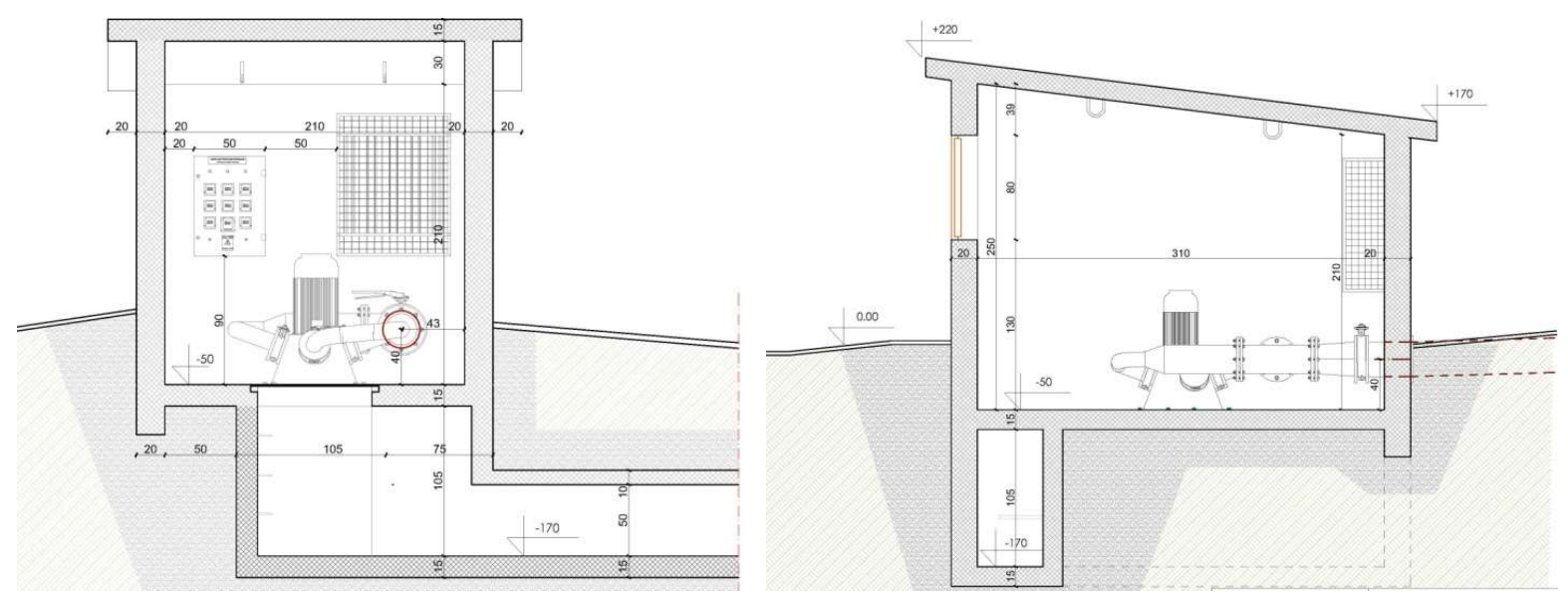

Figure 6. Top and front view of the micro hydro Turgo turbine house

Figure 7 shows the implementation of the constructed hydro Turgo turbine.

a)

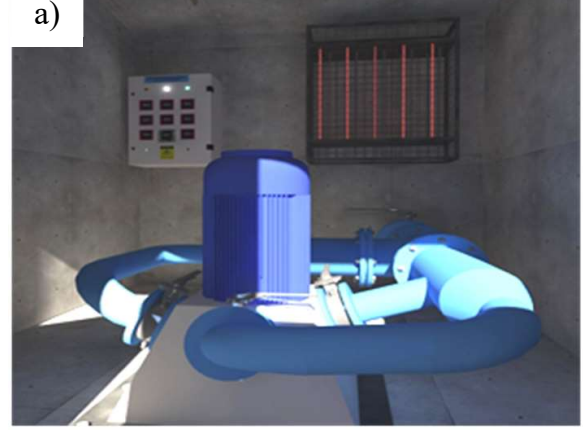

b)

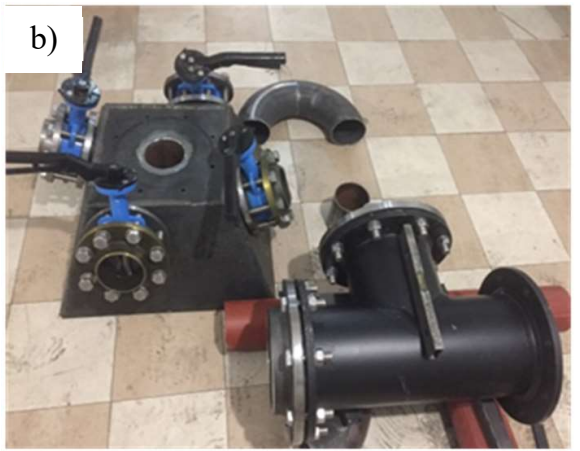

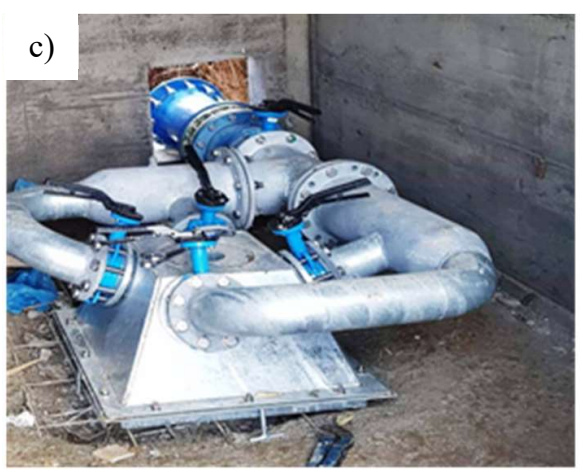

Figure 7. Implementation of the constructed hydro Turgo turbine:

a) turbine fitted in the power house, b) production of the designed parts, and c) installation in hydropower

The power generated from the installed turbine is measured on-site directly through the electric intensity $I[\mathrm{~A}]$ and tension $U[\mathrm{~V}]$. The measurements for different working regimes are shown in Table 4 and compared to the analytical values. The power generated is expressed as the sum of all productions of intensity and tension for all three phases:

$$
P_{\text {out }}=\sum_{i=1}^{n=3} I_{i} \cdot U_{i}=I_{1} \cdot U_{1}+I_{2} \cdot U_{2}+I_{3} \cdot U_{3}[W]
$$


Journal of Thermal Engineering, Research Article, Vol. 7, No. 4, pp. 806-822, May, 2021

Table 4. Net on-site measurements of intensity and tension and output power for the installed hydro Turgo Turbine

\begin{tabular}{|c|c|c|c|c|c|c|c|c|c|}
\hline \multirow{2}{*}{$\begin{array}{c}\text { Working } \\
\text { combinations }\end{array}$} & \multirow{2}{*}{$\begin{array}{l}\text { Active } \\
\text { nozzles }\end{array}$} & \multirow{2}{*}{$\begin{array}{c}\text { Net head, } \\
H_{n}[\mathbf{m}]\end{array}$} & \multicolumn{3}{|c|}{$\begin{array}{c}\text { Intensity for each } \\
\text { phase [A] }\end{array}$} & \multicolumn{3}{|c|}{$\begin{array}{l}\text { Tension for each phase } \\
{[\mathrm{V}]}\end{array}$} & \multirow{2}{*}{$\begin{array}{c}\text { Output power } \\
\text { from generator } \\
P_{\text {out }}[\mathrm{W}]\end{array}$} \\
\hline & & & $\mathrm{I}_{1}$ & $\mathrm{I}_{2}$ & $\mathrm{I}_{3}$ & $\mathrm{U}_{1}$ & $\mathrm{U}_{2}$ & $\mathrm{U}_{3}$ & \\
\hline 1 & 1 & 46.50 & 6.3 & 6.3 & 6.3 & 6.3 & 6.3 & 6.3 & 4347 \\
\hline 2 & 2 & 46.00 & 8.4 & 8.4 & 8.4 & 8.4 & 8.4 & 8.4 & 5796 \\
\hline 3 & 3 & 46.50 & 6.3 & 6.3 & 6.3 & 6.3 & 6.3 & 6.3 & 4347 \\
\hline 4 & 4 & 46.00 & 8.4 & 8.4 & 8.4 & 8.4 & 8.4 & 8.4 & 5796 \\
\hline 5 & $1+2$ & 44.50 & 13.4 & 13.4 & 13.4 & 13.4 & 13.4 & 13.4 & 9246 \\
\hline 6 & $1+3$ & 44.50 & 11.6 & 11.6 & 11.6 & 11.6 & 11.6 & 11.6 & 8004 \\
\hline 7 & $1+4$ & 44.50 & 13.4 & 13.4 & 13.4 & 13.4 & 13.4 & 13.4 & 9246 \\
\hline 8 & $2+3$ & 44.50 & 13.4 & 13.4 & 13.4 & 13.4 & 13.4 & 13.4 & 9246 \\
\hline 9 & $2+4$ & 44.00 & 15 & 15 & 15 & 15 & 15 & 15 & 10350 \\
\hline 10 & $3+4$ & 44.50 & 13.4 & 13.4 & 13.4 & 13.4 & 13.4 & 13.4 & 9246 \\
\hline 11 & $1+2+3$ & 43.00 & 18 & 18 & 18 & 18 & 18 & 18 & 12420 \\
\hline 12 & $1+2+4$ & 42.00 & 19.3 & 19.3 & 19.3 & 19.3 & 19.3 & 19.3 & 13317 \\
\hline 13 & $1+3+4$ & 43.00 & 18 & 18 & 18 & 18 & 18 & 18 & 12420 \\
\hline 14 & $2+3+4$ & 42.00 & 19.3 & 19.3 & 19.3 & 19.3 & 19.3 & 19.3 & 13317 \\
\hline 15 & $1+2+3+4$ & 41.00 & 23.2 & 23.2 & 23.2 & 23.2 & 23.2 & 23.2 & 16008 \\
\hline
\end{tabular}

Whereas, by using the detailed Euler equations through velocity triangles the results of Turgo turbine efficiency for all working combinations are shown in Table 5.

Theoretical calculations are done by assuming that the flow impacts with the cup is a parallel section so the inclination angle is $\gamma=0^{\circ}$ and absolute velocity angles are taken $\alpha_{1}=20^{\circ}$ and $\alpha_{2}=63^{\circ}$.

Table 5. Turgo turbine efficiency calculations for all working combinations by using Euler equations

\begin{tabular}{|c|c|c|c|c|c|c|}
\hline $\begin{array}{c}\text { Working } \\
\text { combinations }\end{array}$ & $\begin{array}{c}\text { Net head, } \\
H_{n}[\mathrm{~m}]\end{array}$ & $\begin{array}{c}\text { Water flow, } \\
\mathrm{m}^{3}\end{array}$ & $\begin{array}{c}\text { Runner } \\
\text { diameter, } \\
D_{r}[\mathrm{~m}]\end{array}$ & $\begin{array}{c}\text { Turbine } \\
\text { output power, } \\
P_{\text {turb }}[W]\end{array}$ & $\begin{array}{c}\text { Power of } \\
\text { water, } \\
P_{\text {water }}[W]\end{array}$ & $\begin{array}{c}\text { Turgo turbine } \\
\text { efficiency } \\
\eta_{\text {turb }}[\%]\end{array}$ \\
\hline 1 & 45.56 & 0.0141 & 0.179 & 5026.55 & 6301.91 & 79.76 \\
\hline 2 & 44.90 & 0.0188 & 0.178 & 6627.45 & 8280.82 & 80.03 \\
\hline 3 & 45.56 & 0.0141 & 0.179 & 5026.55 & 6301.91 & 79.76 \\
\hline 4 & 44.90 & 0.0188 & 0.178 & 6627.45 & 8280.82 & 80.03 \\
\hline 5 & 43.04 & 0.0323 & 0.175 & 11010.20 & 13637.78 & 80.73 \\
\hline 6 & 43.70 & 0.0276 & 0.175 & 9408.10 & 11832.04 & 79.51 \\
\hline 7 & 43.04 & 0.0323 & 0.175 & 11010.20 & 13637.78 & 80.73 \\
\hline 8 & 43.04 & 0.0323 & 0.175 & 11010.20 & 13637.78 & 80.73 \\
\hline 9 & 42.41 & 0.0369 & 0.174 & 12439.49 & 15351.95 & 81.03 \\
\hline 10 & 43.04 & 0.0323 & 0.175 & 11010.20 & 13637.78 & 80.73 \\
\hline 11 & 41.24 & 0.0453 & 0.172 & 14922.63 & 18326.77 & 81.43 \\
\hline 12 & 40.68 & 0.0494 & 0.170 & 15897.47 & 19714.10 & 80.64 \\
\hline 13 & 41.24 & 0.0453 & 0.172 & 14922.63 & 18326.77 & 81.43 \\
\hline 14 & 40.68 & 0.0494 & 0.170 & 15897.47 & 19714.10 & 80.64 \\
\hline 15 & 38.93 & 0.0620 & 0.168 & 19478.96 & 23378.00 & 82.27 \\
\hline
\end{tabular}


Journal of Thermal Engineering, Research Article, Vol. 7, No. 4, pp. 806-822, May, 2021

\section{RESULT DISCUSSION}

By using the calculation method, the results for determining the dimensions and the output power generation of the turbine are shown. Additionally, a comparison was conducted between the measured power generated on-site of the installed hydro Turgo turbine and the analytically yielded results through calculations. In Table 6 the results are presented. The table includes differences between theoretical and measured values of water net head and output power generation of micro Turgo hydro turbine for 8 working condition combinations. Two turbine nozzles have the same diameter $\left(d_{j 1}=d_{j 3}=25 \mathrm{~mm}\right.$ and $\left.d_{j 2}=d_{j 4}=29 \mathrm{~mm}\right)$, therefore the working combination from 16 is reduced to 8.

Table 6. Comparison between theoretical and measured water net head and output power for different working combinations

\begin{tabular}{|c|c|c|c|c|c|c|}
\hline \multirow{2}{*}{$\begin{array}{c}\text { Working } \\
\text { combinations }\end{array}$} & \multicolumn{2}{|c|}{ Theoretical calculation } & \multicolumn{3}{|c|}{ Measured } & \multicolumn{2}{c|}{$\begin{array}{c}\text { Difference between } \\
\text { theoretical and measured, } \\
{[\%]}\end{array}$} \\
\cline { 2 - 7 } & $\begin{array}{c}\text { Net head, } \\
H_{n}[\mathrm{~m}]\end{array}$ & $\begin{array}{c}\text { Output power } \\
P_{\text {out }}[\mathrm{W}]\end{array}$ & $\begin{array}{c}\text { Net head, } \\
H_{n}[\mathrm{~m}]\end{array}$ & $\begin{array}{c}\text { Output power } \\
P_{\text {out }}[\mathrm{W}]\end{array}$ & $\begin{array}{c}\text { Net head, } \\
H_{n}[\mathrm{~m}]\end{array}$ & $\begin{array}{c}\text { Output power } \\
P_{\text {out }}[\mathrm{W}]\end{array}$ \\
\hline $1 ; 3$ & 45.56 & 4275.64 & 46.50 & 4347.00 & $2.03 \%$ & $1.64 \%$ \\
\hline $2 ; 4$ & 44.90 & 5639.64 & 46.00 & 5796.00 & $2.40 \%$ & $2.70 \%$ \\
\hline $5 ; 7 ; 8 ; 10$ & 43.04 & 9268.74 & 44.50 & 9246.00 & $3.29 \%$ & $0.25 \%$ \\
\hline 6 & 43.70 & 8023.81 & 44.50 & 8004.00 & $1.81 \%$ & $0.25 \%$ \\
\hline 9 & 42.41 & 10420.04 & 44.00 & 10350.00 & $3.61 \%$ & $0.68 \%$ \\
\hline $11 ; 13$ & 41.24 & 12453.84 & 43.00 & 12420.00 & $4.08 \%$ & $0.27 \%$ \\
\hline $12 ; 14$ & 40.68 & 13393.41 & 42.00 & 13317.00 & $3.15 \%$ & $0.57 \%$ \\
\hline 15 & 38.93 & 16096.90 & 41.00 & 15180.0 & $5.04 \%$ & $0.56 \%$ \\
\hline
\end{tabular}

Results and differences between predicted and detailed calculation done by Euler equations through velocity triangles, as well as the results of Turgo turbine efficiency for different working combinations are shown in Table 8 . As shown in Table 7, the on-site measured data show a lower power production from the turbine on specific working regimes when compared to the calculated values achieved from the theoretical computations. The difference in results has occurred due to the approximations taken during the calculations.

Table 7. Comparison of turbine efficiency between predicted and estimated outcomes by Euler equations for different working combinations

\begin{tabular}{|c|c|c|c|c|c|}
\hline \multirow{2}{*}{$\begin{array}{c}\text { Working } \\
\text { combinations }\end{array}$} & \multirow{2}{*}{$\begin{array}{c}\text { Net head, } \\
H_{n}[\mathrm{~m}]\end{array}$} & \multirow{2}{*}{$\begin{array}{c}\text { Water flow } \\
Q\left[\mathrm{~m}^{3} / \mathrm{s}\right]\end{array}$} & \multicolumn{2}{|c|}{$\begin{array}{c}\text { Turbine efficiency, } \\
\eta_{\text {turb }}[\%]\end{array}$} & $\begin{array}{c}\text { Difference between } \\
\text { predicted and } \\
\text { calculation, [\%] }\end{array}$ \\
\cline { 4 - 5 } & & & Predicted & Calculated & 0.30 \\
\hline $1 ; 3$ & 45.56 & 0.0141 & 80 & 79.76 & 0.04 \\
\hline $2 ; 4$ & 44.90 & 0.0188 & 80 & 80.03 & 0.92 \\
\hline $5 ; 7 ; 8 ; 10$ & 43.04 & 0.0323 & 80 & 80.73 & 0.61 \\
\hline 6 & 43.70 & 0.0276 & 80 & 79.51 & 1.29 \\
\hline 9 & 42.41 & 0.0369 & 80 & 81.03 & 1.78 \\
\hline $11 ; 13$ & 41.24 & 0.0453 & 80 & 81.43 & 0.80 \\
\hline $12 ; 14$ & 40.68 & 0.0494 & 80 & 80.64 & 2.83 \\
\hline 15 & 38.93 & 0.0620 & 80 & 82.27 & \\
\hline
\end{tabular}

From data given in Table 6 and 7 and the following graphs shown in Figure 8, it is concluded that theoretical results of power generation from the turbine differ to some extent from the measured data. This difference shows as a result of neglecting some of the designed parameters to avoid complex computations. 
Journal of Thermal Engineering, Research Article, Vol. 7, No. 4, pp. 806-822, May, 2021

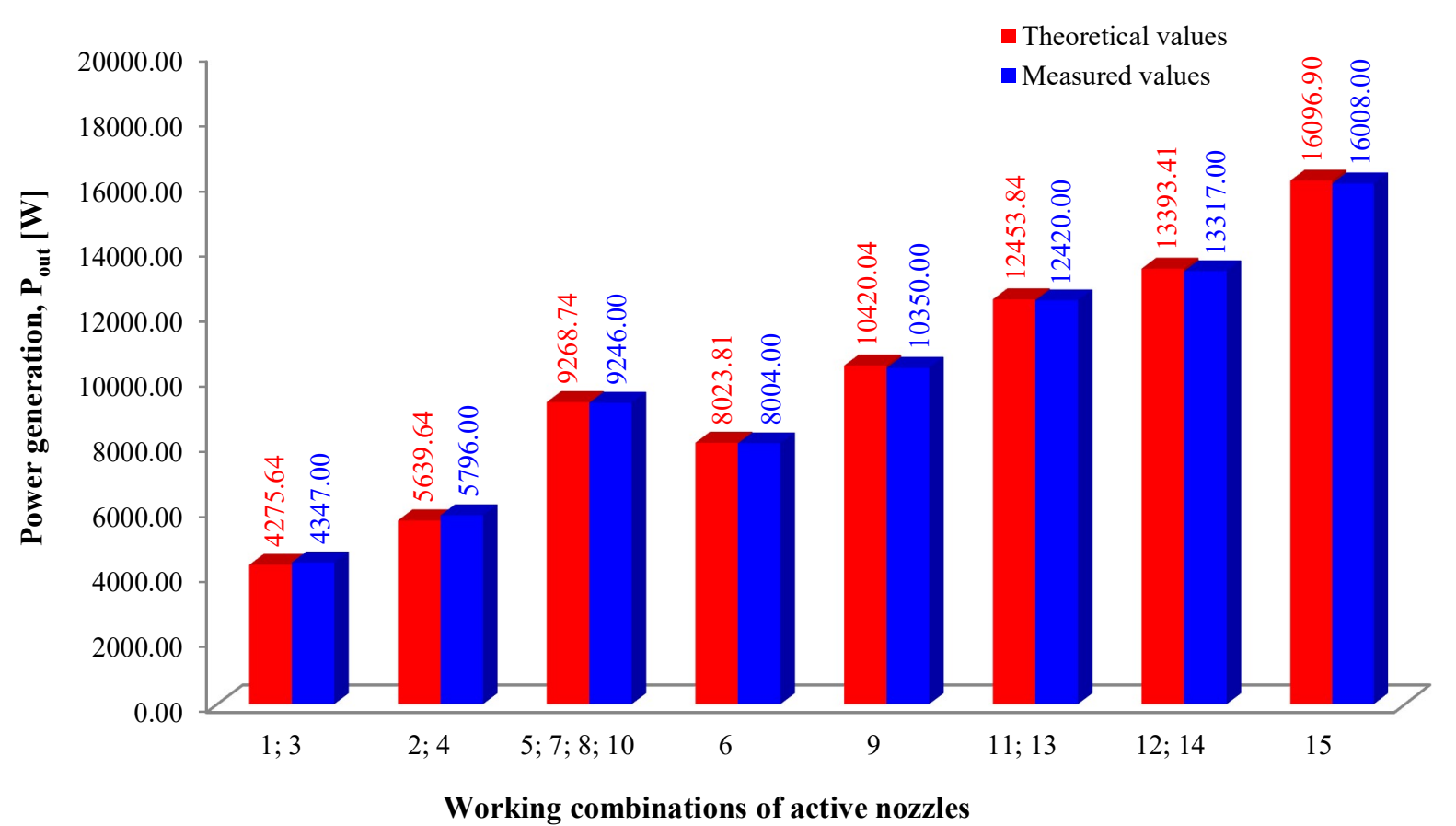

Figure 8. Theoretical and measured values of power generation as a function of the working combinations of active nozzles of the micro hydro Turgo turbine

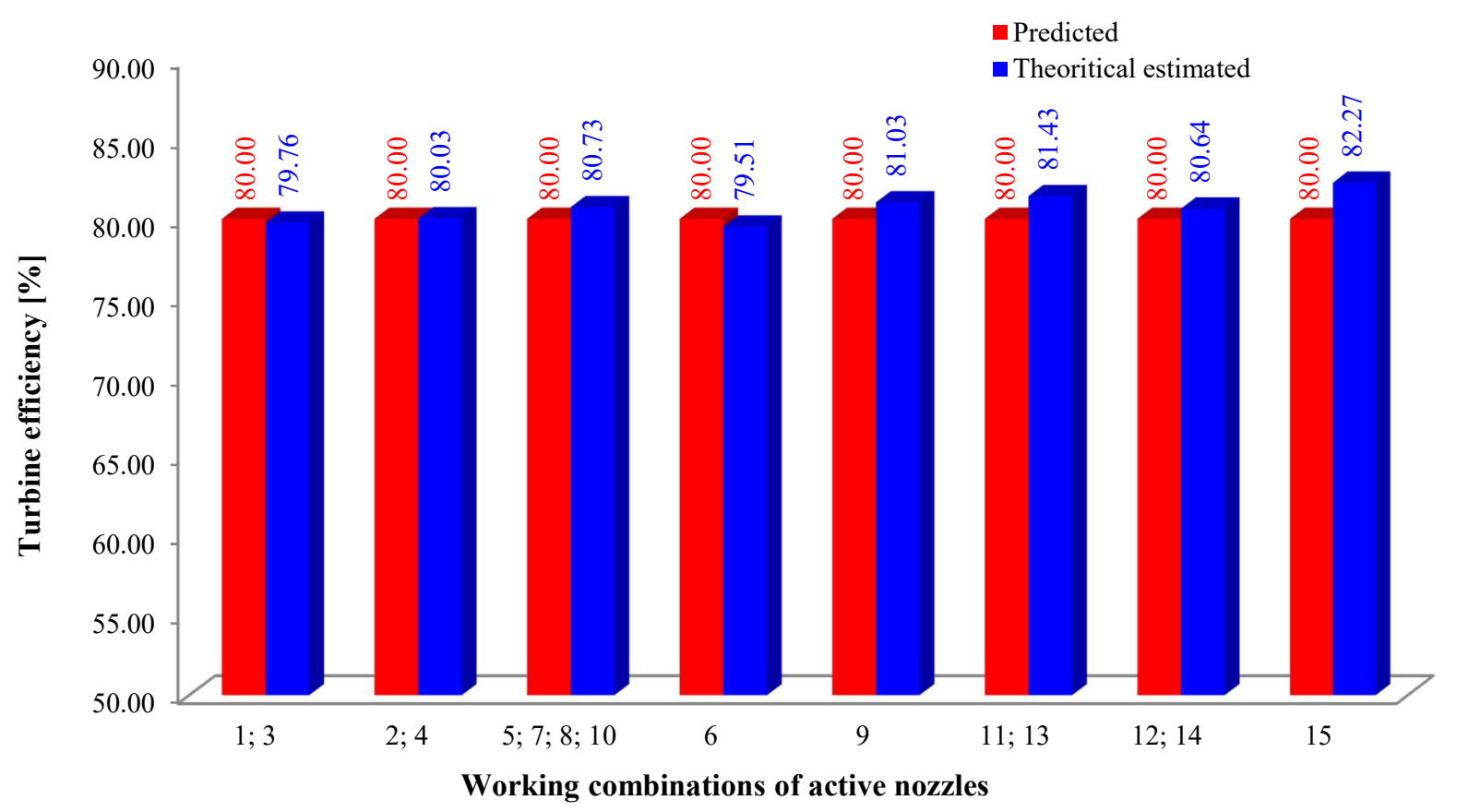

Figure 9. Predicted and estimated values of turbine efficiency as a function of the working combinations of active nozzles of the micro hydro Turgo turbine

Besides the difference of the measured and calculated outcomes, a difference was also noted between the two calculation approaches, based on how detailed the calculations are performed, whether by basic equations or by using detailed Euler equations, the results show that there is a slight change in the outcomes of the computations. 
Journal of Thermal Engineering, Research Article, Vol. 7, No. 4, pp. 806-822, May, 2021

\section{CONCLUSION}

The dearth of green energy and sustainable energy sources present a continuous problem in many countries despite many developments in the energy field, especially in remote locations. Therefore, the implementation of renewable sources in general, and hydro power plants specifically presents an optimal attempt to tackle the energy issues. Thus, this paper presents the design and implementation of a micro-hydropower plant using a Turgo turbine. A comparison was performed between simple and detailed calculation using Euler method to determine the characteristic features of a Turgo turbine for a micro-hydropower plant, designed and implemented in a remote location in Letnicë, Republic of Kosovo, with an installed power of $20[\mathrm{~kW}]$. The yielded results were validated using real on-site measured data. The results showed that the designed parameters of the installed micro hydropower plant will be higher than the real values achieved on-site, due to approximations taken during the analytical calculations and deviations were present depending on the calculation approach. Additionally, a thorough literature review reporting the advances in terms of design and utilization of Turgo turbine in micro hydro power plants was presented.

From experience, it was concluded that construction work and production of micro hydro turbines is possible without highly qualified personnel. Regarding costs, from the installed turbine in the case study it was reckoned that the investment in a micro hydropower plant is affordable and the payback period is shorter compared to other alternative energy sources, as water source is more stable compared to other renewables. The investment costs increase drastically by enlarging penstock diameter even though the energy losses decrease.

Despite the environmental and individual benefits of utilizing micro hydropower plants, researching the potential of water for installing micro hydropower plants also has social benefits in terms of creating employment opportunities, enabling the development of new businesses and overall life improvements of communities.

The elaborated project in this paper has been working since October 2018 and has achieved the predicted results for the estimated power generation.

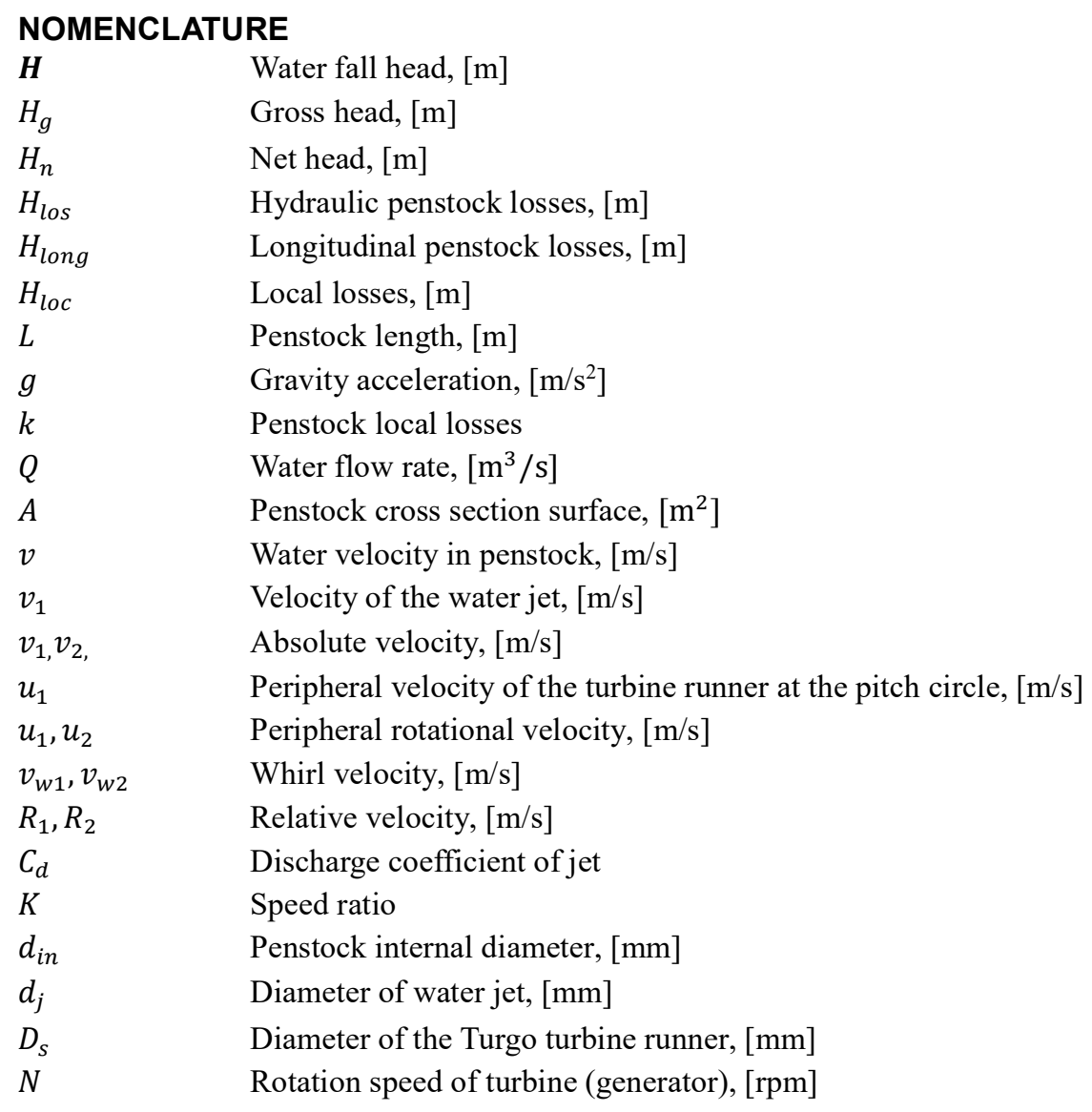




\begin{tabular}{|c|c|}
\hline$P_{\text {out }}$ & Output power from hydro Turgo turbine, [W] \\
\hline$P_{\text {water }}$ & Power of water flow, $[\mathrm{W}]$ \\
\hline$T$ & Torque, $[\mathrm{Nm}]$ \\
\hline$\lambda$ & Pipe friction coefficient \\
\hline$\eta_{\text {turb }}$ & Turbine efficiency, [\%] \\
\hline$\eta_{g e n}$ & Generator efficiency, [\%] \\
\hline$\rho$ & Density of water, $\left[\mathrm{kg} / \mathrm{m}^{3}\right]$ \\
\hline$\alpha_{1}, \alpha_{2}$ & Absolute velocity angle, [deg] \\
\hline$\beta_{1}, \beta_{2}$ & Relative velocity angle, [deg] \\
\hline$\gamma$ & Angle between cup impact plane and vertical, [deg] \\
\hline$\omega$ & Angular velocity, $[\mathrm{rad} / \mathrm{s}]$ \\
\hline
\end{tabular}

\section{REFERENCES}

[1] J. Raabe, Hydro power: the design, use, and function of hydromechanical, hydraulic, and electrical equipment. Düsseldorf: VDI-Verlag, 1985.

[2] "Big Progress for Small Hydro Permitting Reform," Hydro Review, Apr. $01,2013$. https://www.hydroreview.com/2013/04/01/big-progress-for-small-hydro-permitting-reform/ (accessed May 23, 2020).

[3] A. K. Akella, M. P. Sharma, and R. P. Saini, "Optimum utilization of renewable energy sources in a remote area," Renewable and Sustainable Energy Reviews, vol. 11, no. 5, pp. 894-908, Jun. 2007, doi: 10.1016/j.rser.2005.06.006.

[4] C. P. Jawahar and P. A. Michael, "A review on turbines for micro hydro power plant," Renewable and Sustainable Energy Reviews, vol. 72, pp. 882-887, May 2017, doi: 10.1016/j.rser.2017.01.133.

[5] I. Yüksel, "Hydro Energy and Enviromental Policies in Turkey," Journal of Thermal Engineering, Yildiz Technical University Press, Istanbul, Turkey, 2016, doi: 10.18186/jte.26671.

[6] S. Lajqi, N. Lajqi, and B. Hamidi, "Design and Construction of Mini Hydropower Plant with Propeller Turbine," International Journal of Contemporary ENERGY, no. Vol.2. No.1, pp. 1-13, Feb. 2016, doi: 10.14621/ce.20160101.

[7] B. R. Cobb and K. V. Sharp, "Impulse (Turgo and Pelton) turbine performance characteristics and their impact on pico-hydro installations," Renew. Energy, vol. 50, pp. 959-964, Feb. 2013, doi: 10.1016/j.renene.2012.08.010.

[8] B. Suyesh, V. Parag, D. Keshav, A. M. Ahmed, and O. Abdul-Ghani, "Novel trends in modelling techniques of Pelton Turbine bucket for increased renewable energy production," Renewable and Sustainable Energy Reviews, vol. 112, pp. 87-101, Sep. 2019, doi: 10.1016/j.rser.2019.05.045.

[9] A. Zidonis, D. S. Benzon, and G. A. Aggidis, "Development of hydro impulse turbines and new opportunities," Renew. Sust. Energ. Rev., vol. 51, pp. 1624-1635, Nov. 2015, doi: 10.1016/j.rser.2015.07.007.

[10] D. S. Benzon, G. A. Aggidis, and J. S. Anagnostopoulos, "Development of the Turgo Impulse turbine: Past and present," Appl. Energy, vol. 166, pp. 1-18, Mar. 2016, doi: 10.1016/j.apenergy.2015.12.091.

[11] C. S. Kaunda, C. Z. Kimambo, and T. K. Nielsen, "A technical discussion on microhydropower technology and its turbines," Renewable and Sustainable Energy Reviews, vol. 35, pp. 445-459, Jul. 2014, doi: 10.1016/j.rser.2014.04.035.

[12] S. J. Williamson, B. H. Stark, and J. D. Booker, "Performance of a low-head pico-hydro Turgo turbine," Applied Energy, vol. 102, pp. 1114-1126, Feb. 2013, doi: 10.1016/j.apenergy.2012.06.029.

[13] K. Gaiser, P. Erickson, P. Stroeve, and J.-P. Delplanque, “An experimental investigation of design parameters for pico-hydro Turgo turbines using a response surface methodology," Renew. Energy, vol. 85, pp. 406-418, Jan. 2016, doi: 10.1016/j.renene.2015.06.049.

[14] G. Ranjitkar, J. Huang, and T. Tung, “Application of Micro-Hydropower Technology for Remote Regions,” in 2006 IEEE EIC Climate Change Conference, May 2006, pp. 1-10, doi: 10.1109/EICCCC.2006.277207.

[15] Y. R. Pasalli and A. B. Rehiara, "Design Planning of Micro-hydro Power Plant in Hink River," Procedia Environmental Sciences, vol. 20, pp. 55-63, 2014, doi: 10.1016/j.proenv.2014.03.009.

[16] K. Kusakana, "A survey of innovative technologies increasing the viability of micro-hydropower as a cost effective rural electrification option in South Africa," Renew. Sust. Energ. Rev., vol. 37, pp. 370-379, Sep. 2014, doi: 10.1016/j.rser.2014.05.026.

[17] S. Nababan, E. Muljadi, and F. Blaabjerg, "An overview of power topologies for micro-hydro turbines," in 
$20123^{\text {rd }}$ IEEE International Symposium on Power Electronics for Distributed Generation Systems (PEDG), Jun. 2012, pp. 737-744, doi: 10.1109/PEDG.2012.6254084.

[18] Budiarso, Warjito, M. N. Lubis, and D. Adanta, "Performance of a Low Cost Spoon-Based Turgo Turbine for Pico Hydro Installation," in 5th International Conference on Power and Energy Systems Engineering (cpese 2018), vol. 156, H. Bevrani, Ed. Amsterdam: Elsevier Science Bv, 2019, pp. 447-451.

[19] Budiarso, D. Febriansyah, Warjito, and D. Adanta, "The effect of wheel and nozzle diameter ratio on the performance of a Turgo turbine with pico scale," Energy Rep., vol. 6, pp. 601-605, Feb. 2020, doi: 10.1016/j.egyr.2019.11.125.

[20] S. J. Williamson, B. H. Stark, and J. D. Booker, "Experimental optimisation of a low-head pico hydro turgo turbine," in 2012 IEEE Third International Conference on Sustainable Energy Technologies (ICSET), Sep. 2012, pp. 322-327, doi: 10.1109/ICSET.2012.6357419.

[21] J. L. Clarembaux Correa, J. De Andrade, R. Noguera, S. Croquer, F. Jeanty, and M. Asuaje, Design Procedure for a Turgo Type Turbine Using a Three-Dimensional Potential Flow. New York: Amer Soc Mechanical Engineers, 2012, pp. 2039-2052.

[22] O. B. Yaakob, Y. M. Ahmed, A. H. Elbatran, and H. M. Shabara, "A Review on Micro Hydro Gravitational Vortex Power and Turbine Systems,” J. Teknol., vol. 69, no. 7, 2014.

[23] P. K. Koukouvinis, J. S. Anagnostopoulos, and D. E. Papantonis, "SPH Method used for Flow Predictions at a Turgo Impulse Turbine: Comparison with Fluent," vol. 5, no. 7, p. 8, 2011.

[24] J. S. Anagnostopoulos, P. K. Koukouvinis, F. G. Stamatelos, and D. E. Papantonis, Optimal Design and Experimental Validation of a Turgo Model Hydro Turbine. New York: Amer Soc Mechanical Engineers, 2012, pp. 157-166.

[25] Warjito, Budiarso, A. I. Siswantoro, D. Adanta, M. Kamal, and R. Dianofitra, "Simple Bucket Curvature for Designing a Low-Head Turgo Turbine for Pico Hydro Application,” Int. J. Technol., vol. 8, no. 7, pp. 12391247, Dec. 2017, doi: 10.14716/ijtech.v8i7.767.

[26] S. Khurana, V. Goel, and A. Kumar, "FEM Analysis of Turgo Impulse Turbine Blade," Walailak Journal of Science and Technology (WJST), vol. 10, no. 4, pp. 363-368, Apr. 2013.

[27] S. Khurana, Varun, and A. Kumar, "Effect of silt particles on erosion of Turgo impulse turbine blades," Int. J. Ambient Energy, vol. 35, no. 3, pp. 155-162, 2014, doi: 10.1080/01430750.2013.789985.

[28] S. Khurana and V. Goel, "Effect of jet diameter on erosion of turgo impulse turbine runner," J. Mech. Sci. Technol., vol. 28, no. 11, pp. 4539-4546, Nov. 2014, doi: 10.1007/s12206-014-1021-6.

[29] S. Khurana, V. Goel, and G. Singh, Effect of Silt and Jet Diameter on Performance of Turgo Impulse Hydro Turbine. New York: Amer Soc Mechanical Engineers, 2017, p. UNSP V01AT03A030.

[30] "Creating the ultimate hybrid system by mixing solar energy and hydroelectricity - Renewable Energy Focus." http://www.renewableenergyfocus.com/view/45793/creating-the-ultimate-hybrid-system-by-mixing-solarenergy-and-hydroelectricity/ (accessed May 24, 2020).

[31] R. Muhida, A. Mostavan, W. Sujatmiko, M. Park, and K. Matsuura, "The 10 years operation of a PV-microhydro hybrid system in Taratak, Indonesia," Solar Energy Materials and Solar Cells, vol. 1-4, no. 67, pp. 621627, 2001.

[32] E. M. Nfah and J. M. Ngundam, "Feasibility of pico-hydro and photovoltaic hybrid power systems for remote villages in Cameroon," Renewable Energy, vol. 34, no. 6, pp. 1445-1450, Jun. 2009, doi: 10.1016/j.renene.2008.10.019.

[33] S. Lajqi, X. Fejzullahu, N. Lajqi, and H. Hajdini, "Analysis of the Mini Turgo Hydro Turbine Performance for different Working Regimes," 2017.

[34] S. Lajqi, D. Meha, X. Berisha, B. Đurin, and L. Baić, "The infrastructure of Renewable Energy Sources for Sustainable Development in Kosovo," 12th SDEWES Conference Dubrovnik 2017, p. 445, Oct. 2017.

[35] A. W. Dametew, "Design and Analysis of Small Hydro Power for Rural Electrification,” p. 23, 2016.

[36] A. Chauhan and R. P. Saini, "Renewable energy based off-grid rural electrification in Uttarakhand state of India: Technology options, modelling method, barriers and recommendations," Renewable and Sustainable Energy Reviews, vol. 51, pp. 662-681, Nov. 2015, doi: 10.1016/j.rser.2015.06.043.

[37] A. H. Elbatran, O. B. Yaakob, Y. M. Ahmed, and H. M. Shabara, "Operation, performance and economic analysis of low head micro-hydropower turbines for rural and remote areas: A review," Renewable and Sustainable Energy Reviews, vol. 43, pp. 40-50, Mar. 2015, doi: 10.1016/j.rser.2014.11.045.

[38] “Turbína TURGO.” http://mve.energetika.cz/primotlaketurbiny/turgo.htm (accessed May 24, 2020). 